\title{
Charles Mazouer, Geste et parole chez les acteurs italiens en France ( $\mathrm{XVI}^{\mathrm{e}}-\mathrm{XVII}{ }^{\mathrm{e}}$ siècles)
}

\section{Maurizio Busca}

\section{(2) OpenEdition}

\section{Journals}

\section{Edizione digitale}

URL: http://journals.openedition.org/studifrancesi/4342

DOI: 10.4000/studifrancesi.4342

ISSN: 2427-5856

\section{Editore}

Rosenberg \& Sellier

\section{Edizione cartacea}

Data di pubblicazione: 1 settembre 2016

Paginazione: 319

ISSN: 0039-2944

\section{Notizia bibliografica digitale}

Maurizio Busca, "Charles Mazouer, Geste et parole chez les acteurs italiens en France (xv1 ${ }^{\mathrm{e}}$-xvI" siècles) 》, Studi Francesi [Online], 179 (LX | II) | 2016, online dal 01 septembre 2016, consultato il 18 septembre 2020. URL : http://journals.openedition.org/studifrancesi/4342 ; DOI : https://doi.org/10.4000/ studifrancesi.4342

Questo documento è stato generato automaticamente il 18 settembre 2020.

\section{(c) (i) (9)}

Studi Francesi è distribuita con Licenza Creative Commons Attribuzione - Non commerciale - Non opere derivate 4.0 Internazionale. 


\title{
Charles Mazouer, Geste et parole chez les acteurs italiens en France (XVI ${ }^{\mathrm{e}}-\mathrm{XVII}{ }^{\mathrm{e}}$ siècles)
}

\author{
Maurizio Busca
}

\section{NOTIZIA}

CHARLES MAZOUER, Geste et parole chez les acteurs italiens en France (XVI $\mathrm{e}^{\mathrm{e}} \mathrm{XVII} \mathrm{e}^{\mathrm{e}}$ siècles), in La scène en version originale, sous la direction de Julie Vatain-Corfdir, Paris, Presses de l'Université Paris-Sorbonne, 2015,9-16 pp.

1 Si segnala, all'interno di un volume dedicato alla rappresentazione di spettacoli teatrali in una lingua diversa da quella del pubblico, il contributo di Charles MAZOUER sulle compagnie italiane, itineranti e fisse, che fra Cinque e Seicento hanno portato sulle scene francesi la commedia dell'arte. L'A. si sofferma su questioni concernenti la lingua impiegata (inizialmente il solo italiano, quindi una commistione di italiano e francese, e nell'ultimo scorcio del xvII secolo talvolta il solo francese), l'uso di oggetti sulla scena (che poteva giungere a «évacu[er] pratiquement la parole», p. 14) e soprattutto il ruolo preminente del gesto, che nel caso degli spettacoli per il pubblico cittadino (presso il quale la conoscenza della lingua italiana, al contrario di quanto avveniva a corte, era poco diffusa) poteva divenire non solo un complemento, ma un sostituto del dialogo. Evocando alcuni fra i personaggi e i momenti più significativi della storia del teatro italiano in Francia, l'A. non manca di ricordare l'importanza dell'eredità di questa lunga stagione: dal ricorso, già nel Cinquecento, ad attrici per interpretare i ruoli femminili, all'influenza esercitata nel secolo successivo su Molière. 